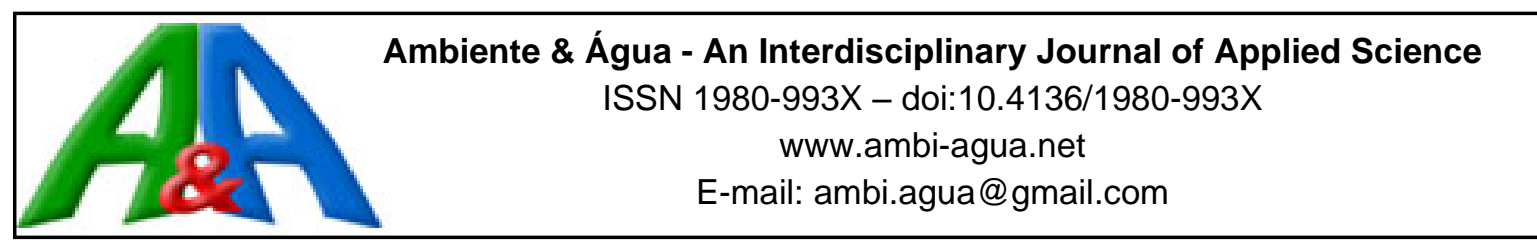

\title{
Physical fractions of organic matter and mineralizable soil carbon in forest fragments of the Atlantic Forest
}

\author{
ARTICLES doi:10.4136/ambi-agua.2601
}

Received: 18 Jun. 2020; Accepted: 28 Sep. 2020

\author{
Jefferson Matheus Barros Ozório ${ }^{1 *}$ (D) Jean Sérgio Rosset ${ }^{1}$; \\ Jolimar Antonio Schiavo ${ }^{2}$; Camila Beatriz da Silva Souza ${ }^{1}$; \\ Paulo Guilherme da Silva Farias ${ }^{2}$; Naelmo de Souza Oliveira ${ }^{2}$; \\ Roniedison da Silva Menezes ${ }^{2}$; Eloi Panachuki² ${ }^{2}$
}

\begin{abstract}
${ }^{1}$ Departamento de Gestão Ambiental. Universidade Estadual de Mato Grosso do Sul (UEMS), BR-163, Km 20,2, CEP: 79980-000, Mundo Novo, MS, Brazil. E-mail: rosset@uems.br, camilabeatrizss@ hotmail.com ${ }^{2}$ Departamento de solos. Universidade Estadual de Mato Grosso do Sul (UEMS), Rodovia Graziela Barroso, Km 12 Zona Rural, caixa postal 25, CEP: 79200-000, Aquidauana, MS, Brazil. E-mail: schiavo@uems.br, pauloguilhermesf@hotmail.com, naelmo-95@hotmail.com, roniedison1@ hotmail.com, eloip@uems.br *Corresponding author. E-mail: ozorio.jmb@outlook.com
\end{abstract}

\begin{abstract}
This study determined the physical granulometric fractionation evaluated the mineralizable carbon within and around forest fragments of the Atlantic Forest biome located in the state of Paraná. Soil samples were collected at three three internal points of the fragments: the edge $(\mathrm{E})$, the half radius (HR) and the center (CF); and one point in no-tillage system (NTS) areas around the fragments, in four replicates. The contents of total organic carbon (TOC), particulate fraction carbon (C-POM) and mineral fraction (C-MOM) were determined, and the \%POM and $\% \mathrm{MOM}$ and the stocks of POM (StockPOM) and MOM (StockMOM) were calculated, in addition to the indices: carbon stock index (CSI), lability (L), lability index (LI) and carbon management index (CMI), also evaluating $\mathrm{CO}_{2}$ emission, daily and accumulated. The highest TOC levels were observed in the CF point. The highest C-POM contents were observed in the $\mathrm{E}$ and $\mathrm{CF}$ points of fragment 1 , in the $\mathrm{CF}$ point of fragment 2 , and the highest C-MOM contents were expressed in the $\mathrm{CF}$ points of both fragments. CMI showed a distinct pattern among the fragments. The NTS areas showed lower $\mathrm{C}-\mathrm{CO}_{2}$ emissions, with $39.8 \%$ and $28.3 \%$ less total emission compared to $\mathrm{CF}$. The results of physical granulometric fractionation show the $\mathrm{CF}$ point favors the quality of SOM and the mineralizable carbon analysis indicated that the conversion of native areas into NTS compromises soil microbial activity.
\end{abstract}

Keywords: carbon management, environmental assessment, soil quality.

\section{Frações físicas da matéria orgânica e carbono mineralizável do solo em fragmentos florestais da Mata Atlântica}

\section{RESUMO}

O objetivo do presente trabalho foi determinar o fracionamento físico-granulométrico e avaliar o carbono mineralizável no interior e ao entorno de fragmentos florestais do bioma Mata Atlântica localizados no estado do Paraná. As amostras de solo foram coletas em três de três pontos internos dos fragmentos: borda (BO), metade do raio (MR) e centro (CF) e um ponto 
em áreas de sistema plantio direto (SPD) no entorno dos fragmentos, em quatro repetições. Foram determinados os teores de carbono orgânico total (COT), carbono da fração particulada (C-MOP) e da fração mineral (C-MOM), sendo calculados as \%MOP e \%MOM e os estoques de MOP (Est. MOP) e de MOM (Est. MOM), além dos índices: índice de estoque de carbono (IEC), labilidade (L), índice de labilidade (IL) e índice de manejo de carbono (IMC), avaliando ainda a emissão de $\mathrm{CO}_{2}$, diária e acumulada. Os maiores teores de COT foram observados no ponto $\mathrm{CF}$. Os maiores teores de $\mathrm{C}$-MOP foram observados nos pontos $\mathrm{BO}$ e $\mathrm{CF}$ do fragmento 1, no ponto $\mathrm{CF}$ do fragmento 2, e os maiores teores de $\mathrm{C}-\mathrm{MOM}$ foram expressos no ponto $\mathrm{CF}$ de ambos os fragmentos. O IMC apresentou padrão distinto entre os fragmentos. As áreas de SPD apresentaram menor emissão de $\mathrm{C}-\mathrm{CO}_{2}$, com $39,8 \%$ e $28,3 \%$ menos emissão total em relação ao $\mathrm{CF}$. Os resultados do fracionamento físico-granulométrico mostram o ponto $\mathrm{CF}$ favorece a qualidade da MOS e a análise de carbono mineralizável indicou que a conversão de áreas nativas em SPD compromete a atividade microbiana do solo.

Palavras-chave: avaliação ambiental, manejo de carbono, qualidade do solo.

\section{INTRODUCTION}

The effect of anthropization on the Brazilian Atlantic Forest biome has generated several impacts on the landscape in general, among them, the increase in forest fragmentation stands out (Warburton, 1997). Forest fragments were defined by Viana and Pinheiro (1998) as areas of natural vegetation interrupted by natural barriers (mountains, rivers, lakes, among others), or anthropic barriers (roads, agricultural activities, cities), which interfere with the flow of fauna, pollen and seed dispersal.

Forest fragmentation is a phenomenon distributed throughout large natural areas, shaping the landscape in general (Viana et al., 1997), restricting the survival of biodiversity to these areas, making the remaining fragments extremely important for the conservation biology (Warburton, 1997). The consequence of forest fragmentation is mainly reflected in the decrease, and even in the extinction of fauna (Pereira and Neves, 2007; Laurance and Vasconcelos, 2009) and flora (Souza et al., 2015). A major problem when thinking about forest fragments is the non-connectivity between them, which would allow greater survival of species due to the greater effectiveness of gene flow (Viana and Pinheiro, 1998).

With the forest fragmentation of Brazilian biomes, the species are exposed to physical and biotic changes, causing the so-called "edge effect" in the fragments. This effect occurs near the edge of the fragment, where there is greater sensitivity to external agents, making more noticeable the various forms of changes, such as vegetation variation, with changes in edaphic attributes over time, due to several regional factors (Malchow et al., 2017).

Changes in edaphic attributes in forest fragments as a function of the edge effect are not yet well defined, and may differ from one region to another (Primack and Rodrigues, 2001). Thus, there is no defined pattern for the exact point at which microclimatic, vegetation and soil changes on the edge effect can be noticeable by entering the forest fragment, as it depends on numerous factors (Kapos, 1989).

Barros and Fearnside (2016), studying carbon stock (C) on the edges of forest fragments in the Amazon biome, reported an increase in soil $\mathrm{C}$ stock in the first meters entering the fragments, when compared to areas of 300 meters within these fragments. However, studies that present the effects that fragmentation and edge effect can cause in $\mathrm{C}$ and in the edaphic characteristics of Brazilian biomes are still incipient in the literature (Ozório et al., 2019).

Soil organic matter (SOM) studies based on $\mathrm{C}$ contents are sensitive in identifying changes in soil management and mainly in vegetation modifications (Souza et al., 2019; Ferreira et al., 2020). The fact that the $C$ content is immediately changed when the vegetation is modified occurs by the change in the input of SOM by the deposition of dry mass (Lal, 2018; Assunção

Rev. Ambient. Água vol. 15 n. 6, e2601 - Taubaté 2020 
et al., 2019).

Another way to evaluate the edaphic quality and possible changes caused by the management and alteration of natural vegetation is the fractionation of SOM, mainly due to its high diversity in oxidation state, chemical composition, size, lability and recalcitrance (Rangel and Silva, 2007). Thus, physical granulometric fractionation of SOM, which quantifies labile and recalcitrant fractions, is an important environmental assessment tool (Rosset et al., 2019b). In addition to the forms of fractionation, the evaluation of soil mineralizable carbon is another variable that contributes to evaluate soil biological quality (Borges et al., 2016; Rosset et al., 2019a), through the emission of $\mathrm{CO}_{2}$, product of the activity of microorganisms that decompose SOM (Rosset et al., 2019b).

Thus, studies evaluating soil quality with analytical techniques that are sensitive in identifying changes in soil and vegetation management are of great scientific importance and are also important for the conservation of existing forest fragments. The hypothesis of the work is that the interior of the forest fragments present quantity and quality of the MOS, as they do not suffer from a possible edge effect. Therefore, this study determined the labile and recalcitrant fractions of carbon through physical granulometric fractionation, and evaluated the mineralizable carbon within forest fragments and in areas managed around forest fragments of the Atlantic Forest biome.

\section{MATERIAL AND METHODS}

\subsection{Location, Climate, Soil and History of Study Areas}

Soil samples were collected from two forest fragments located in the municipality of Terra Roxa, western Paraná state, Brazil (Figure 1, Table 1). The vegetation of the two fragments is of Atlantic Forest - Semideciduous Seasonal Forest (Campos and Silveira Filho, 2010), the two fragments are rectangular, with a proximity of $50 \mathrm{~m}$ from one another.

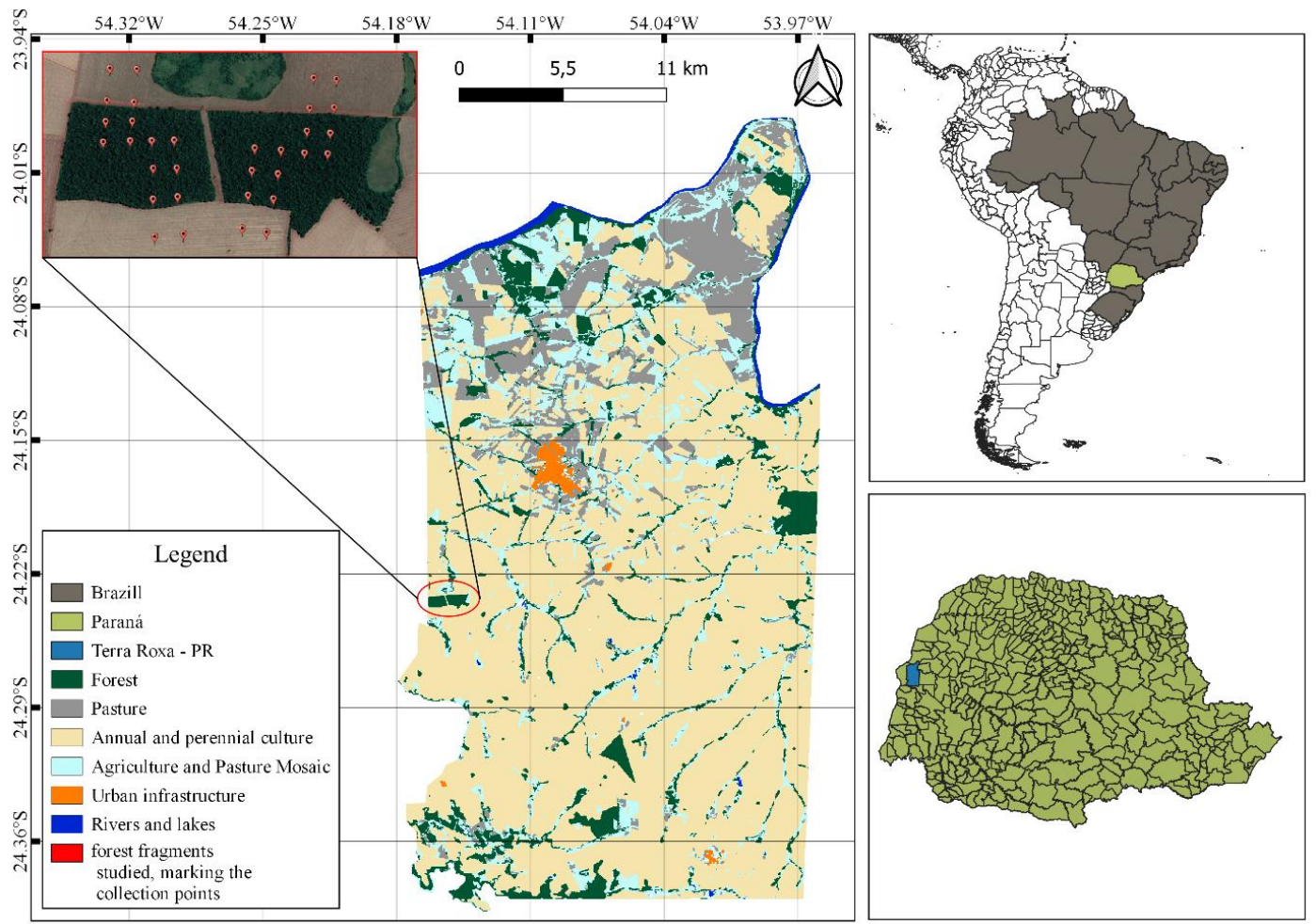

Figure 1. Location map with the main land-use activities, assessed fragments and sampling points, in which each sampled point represents a repetition, in the municipality of Terra Roxa - PR. 
Table 1. Descriptions of the areas of the forest fragments evaluated.

\begin{tabular}{|c|c|}
\hline Evaluated fragments & Description \\
\hline Fragment 1 & 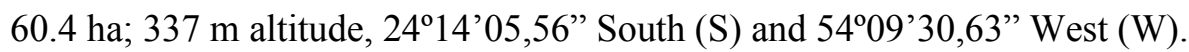 \\
\hline Fragment 2 & 69.1 ha; $338 \mathrm{~m}$ altitude, $24^{\circ} 14^{\prime} 04,37^{\prime \prime}$ South (S) and $54^{\circ} 08^{\prime} 51,89^{\prime \prime}$ West (W). \\
\hline
\end{tabular}

The climate of the area is subtropical (Cfa), according to Köppen classification (Caviglione et al., 2000). According to the detailed survey of soils of Paraná state (Bhering et al., 2007), the study areas are under typical Eutrophic Red Latosol (Santos et al., 2018), very clayey texture (58.0, 249.8, 692.2 $\mathrm{g} \mathrm{kg}^{-1}$ of sand, silt and clay, respectively in Fragment 1, and 57.6, 242.4, $701.0 \mathrm{~g} \mathrm{~kg}^{-1}$ of sand, silt and clay, respectively in Fragment 2) (Santos et al., 2018), and the chemical characterization of the studied points is presented in Table 2.

Table 2. Chemical characterization of the studied points in Fragments 1 and 2 and in the surrounding NTS areas.

\begin{tabular}{ccccc}
\hline Determinations & $\begin{array}{c}\text { Points E, HR and CF of } \\
\text { Fragment 1 }\end{array}$ & $\begin{array}{c}\text { Points E, HR and CF of } \\
\text { Fragment 2 }\end{array}$ & $\begin{array}{c}\text { NTS around } \\
\text { Fragment 1 }\end{array}$ & $\begin{array}{c}\text { NTS around } \\
\text { Fragment 2 }\end{array}$ \\
\hline $\mathrm{pH}\left(\mathrm{CaCl} l_{2}\right.$ & 4.8 & 4.7 & 5.1 & 5.1 \\
$0.01 \mathrm{M})$ & 8.1 & 4.1 & 10.8 & 30.1 \\
$\mathrm{P}\left(\mathrm{mg} / \mathrm{dm}^{3}\right)$ & 0.5 & 0.6 & 0.4 & 0.5 \\
$\mathrm{~K}\left(\mathrm{cmol}_{\mathrm{c}} / \mathrm{dm}^{3}\right)$ & 1.4 & 1.2 & 2.9 & 3.0 \\
$\mathrm{Ca}\left(\mathrm{cmol}_{\mathrm{c}} / \mathrm{dm}^{3}\right)$ & 1.1 & 0.8 & 1.4 & 2.0 \\
$\mathrm{Mg}\left(\mathrm{cmol}_{\mathrm{c}} / \mathrm{dm}^{3}\right)$ & 0.1 & 0.1 & 0.1 & 0.1 \\
$\mathrm{Al}\left(\mathrm{cmol}_{\mathrm{c}} / \mathrm{dm}^{3}\right)$ & 5.0 & 2.2 & 3.2 & 3.5 \\
$\mathrm{H}+\mathrm{Al}^{3}$ & 3.0 & 2.6 & 4.7 & 5.5 \\
$\left(\mathrm{cmol} / \mathrm{dm}^{3}\right)$ & 8.0 & 4.8 & 7.9 & 9.0 \\
$\mathrm{SB}$ & 37.7 & 54.1 & 59.4 & 61.0 \\
$\mathrm{C.E.C}(\mathrm{pH} 7.0)$ & $\mathrm{V} \%$ & & &
\end{tabular}

Laboratory: NUTRISOLO, Ivinhema, MS. Chemical characterization - Calcium Chloride ( $\mathrm{pH}$ ); Mehlich $(\mathrm{P}$ and $\mathrm{K}) ; \mathrm{KCl} 1 \mathrm{~N}(\mathrm{Ca}, \mathrm{Mg}$ and $\mathrm{Al})$; Calcium Acetate $\mathrm{pH} 7.0(\mathrm{H}+\mathrm{Al})$. SB: Sum of bases, C.E.C: Cation exchange capacity, V\%: Base saturation.

Surrounding the two fragments, there are areas of agricultural cultivation under the notillage system (NTS) that total 76.1 ha. The fragments show no difference in management, where these remaining forest fragments were cleared in 1970 for the cultivation of mint for 10 years. From 1980, soybean/corn was cultivated in a conventional tillage system (CTS) until 2002, when the areas were converted to the NTS in the same succession system of CTS crops, which remains to date. However, in these two forest fragments, until 2000, there was forest management with removal of larger trees from the outermost areas, that is, until this year, anthropic actions existed within these fragments modifying their vegetation.

\subsection{Soil sample collections}

Soil collections were performed at four points, three points within the fragments and one point around them, in the NTS areas. The internal points correspond to the edge of the fragment (E), the central point between the edge and the center of the fragment, called half radius (HR), the center of the fragment $(\mathrm{CF})$, and the point external to the fragments in the NTS areas surrounding the fragments. The layout of the points is described in Table 3. 
Table 3. Description of the collection points in the fragments and their distance from the edge of the fragments.

\begin{tabular}{cccc}
\hline & & Fragments (distance (m) from the edge) \\
\hline & \multicolumn{2}{c}{ Fragments } \\
\hline Collection point & \multicolumn{1}{c}{ Description of the point } & $\mathbf{1}$ & $\mathbf{2}$ \\
P. 1 & Center of the fragment (CF) & 310 & 310 \\
P. 2 & Half the radius of the fragment (HR) & 155 & 155 \\
P. 3 & Edge of the fragment (E) & 0 & 0 \\
P. 4 & Outside of the fragment (NTS) & 310 & 310 \\
\hline
\end{tabular}

For each collection point, 4 replicates were performed in a radius of $20 \mathrm{~m}^{2}$. Samples of disturbed and undisturbed soils were collected in the interior, and in the NTS areas around the fragments. The undisturbed samples to evaluate soil density (Ds) were collected with the aid of a volumetric ring with volume of $48.86 \mathrm{~cm}^{3}$. The disturbed samples were acquired with the aid of auger, by collecting three simple samples, in the layers of 0-0.05, 0.05-0.1 and 0.1-0.2 m. Some disturbed samples of the $0-0.05 \mathrm{~m}$ layer were immediately refrigerated for analysis of C$\mathrm{CO}_{2}$ (mineralizable carbon) evolution.

\subsection{Analyses Performed}

After collection, the disturbed samples were air-dried, disaggregated and passed through a $2 \mathrm{~mm}$ sieve to obtain thin air-dried soil (TADS). The total organic carbon (TOC) was determined by the oxidation of organic matter by potassium dichromate, in a sulfuric medium under heating, and titrated with ammoniacal ferrous sulfate (Yeomans and Bremner, 1988).

The physical granulometric fractionation of the SOM was performed following the methodology of Cambardella and Elliott (1992), in which $20 \mathrm{~g}$ of TADS, together with $60 \mathrm{ml}$ of sodium hexametaphosphate $\left(5 \mathrm{~g} \mathrm{~L}^{-1}\right)$ were placed in $250 \mathrm{ml}$ Erlenmeyer, stirred for 16 hours on an agitating table at a speed of $150 \mathrm{rpm}$. After the stirring period, the samples were washed in a $53 \mu \mathrm{m}$ sieve, and the material retained in the sieve consisted of particulate organic matter (POM), obtaining later, by the methodology of Yeomans and Bremner (1988), the carbon of particulate organic matter (C-POM) and, through the difference between TOC and C-POM, the carbon of mineral organic matter (C-MOM) was obtained.

After carbon determinations of the physical granulometric fractions of the SOM, indices were calculated to evaluate the quality of the SOM, which were; carbon stock index (CSI) (Equation 1), SOM lability (L) (Equation 2), lability index (LI) (Equation 3) and carbon management index (CMI) (Equation 4), calculated according to Blair et al. (1995).

$$
\begin{aligned}
& \text { CSI }=\frac{\text { TOC Treatment }}{\text { TOC Reference }} \\
& \mathrm{L}=\frac{\text { C-POM }}{\text { C-MOM }} \\
& \mathrm{LI}=\frac{\mathrm{L} \text { Treatment }}{\mathrm{L} \text { Reference }} \\
& \mathrm{CMI}=\text { CSI } \times \text { LI } \times 100
\end{aligned}
$$

Where:

CSI = Carbon stock index;

TOC Treatment $=$ Stock TOC $\left(\mathrm{Mg} \mathrm{ha}^{-1}\right)$ in the evaluated management system;

TOC Reference $=$ Stock TOC $\left(\mathrm{Mg} \mathrm{ha}^{-1}\right)$ in the reference system; L = lability of SOM;

C-POM = Carbon of particulate organic matter; 
C-MOM = Carbon of mineral organic matter;

$\mathbf{L I}=$ Lability index of the management system under analysis;

L Treatment $=$ Lability of SOM in the management system under analysis;

L Reference $=$ Lability of SOM in the reference system;

$\mathbf{C M I}=$ Carbon management index .

For the calculations of carbon stock of particulate organic matter (StockC-POM) and carbon stock of mineral organic matter (StockC-MOM), the soil density of the undisturbed samples was determined according to Claessen (1997), and the stocks were calculated according to the equivalent mass method (Equation 5) (Reis et al., 2018; Signor et al., 2014).

Equivalent mass method $=(\mathrm{Sd}$ of the evaluated treatment $\mathrm{x}$ Corrected thickness $\mathrm{x}$ Content $(\mathrm{C}-$ POM, C - MOM)) / Rated thickness

Where:

Sd of the evaluated treatment $=$ Soil density of the evaluated treatment;

Corrected thickness $=$ Corrected soil thickness (Average treatment density / average reference density $\mathrm{x}$ evaluated thickness);

Content $($ C-POM, C-MOM) $=$ Carbon content of particulate organic matter to result in MOP stock, and mineral organic matter to result in MOM stock, of the evaluated treatments;

Rated thickness $=$ Soil thickness sampled.

The analysis of the mineralizable carbon emission $\left(\mathrm{C}-\mathrm{CO}_{2}\right)$, was carried out following the methodology of Mendonça and Matos (2005). Thus, $50 \mathrm{~g}$ of soil were placed inside a plastic container of $3 \mathrm{~L}$ capacity, together with a glass container with $30 \mathrm{ml}$ of $0.5 \mathrm{~mol} \mathrm{~L}^{-1} \mathrm{NaOH}$ solution to capture the C-CO $\mathrm{CO}_{2}$ emitted, and a flask with $30 \mathrm{ml}$ of $\mathrm{H}_{2} \mathrm{O}$ in order to maintain constant moisture. The plastic container was hermetically sealed. Each day of evaluation, 10 $\mathrm{ml}$ of $\mathrm{NaCl}_{2}$ were removed from the glass container, and $10 \mathrm{ml}$ of $\mathrm{BaCl}_{2} 0.05 \mathrm{~mol} \mathrm{~L}^{-1}$ and 4 drops of phenolphthalein $1 \%$ were added, with subsequent titration with $\mathrm{HCl} 0.25 \mathrm{~mol} \mathrm{~L}^{-1}$. After removing the $30 \mathrm{~mL}$ container of $0.5 \mathrm{~mol} \mathrm{~L}^{-1} \mathrm{NaOH}$ solution, a new container with $30 \mathrm{~mL}$ was inserted for the next evaluation, leaving the plastic container open for 15 minutes to change the air before the next incubation. The titrations/evaluations were performed at 24-hour intervals in the first 7 days, $48 \mathrm{~h}$ between the 8th and 17th day, and $96 \mathrm{~h}$ between the 18th and 33rd day, as performed by Loss et al. (2013) and Rosset et al. (2019b).

The results obtained met the assumptions of normality and homogeneity of variance by means of the Shapiro-Wilk test and Bartlett's test. Subsequently, in a completely randomized design, the results were submitted to variance analysis with application of the F test, in isolation, evaluating each fragment individually, and the mean values compared by the Tukey test at 5\% with the aid of the R Core Team program (2019).

\section{RESULTS AND DISCUSSION}

The forest fragments of the Atlantic Forest biome presented the highest levels of TOC in the CF points, differing from the other points within and around the fragments, reaching $63.2 \mathrm{~g}$ $\mathrm{kg}^{-1}$ and $60.9 \mathrm{~g} \mathrm{~kg}^{-1}$ in Fragments 1 and 2, respectively, in the $0-0.05 \mathrm{~m}$ layer in the CF points (Figure 2). In general, the lowest levels of TOC were observed in the areas of NTS around the fragments, with lower levels in the 0.10-0.20 m layer (Figure 2).

The E and HR points showed a decrease in TOC levels in the 0-0.05 m layer when compared to the CF point, with relative reductions of $46.1 \%$ and $28.9 \%$ for Point $\mathrm{E}$, and $47.2 \%$ 
and $34.4 \%$ for Point HR, of Fragments 1 and 2, respectively. The NTS areas showed the greatest reductions in TOC levels when compared to the CF point, with 53.1 and $47.4 \%$ reduction, in the 0-0.05 m layer of Fragments 1 and 2, respectively (Figure 2).

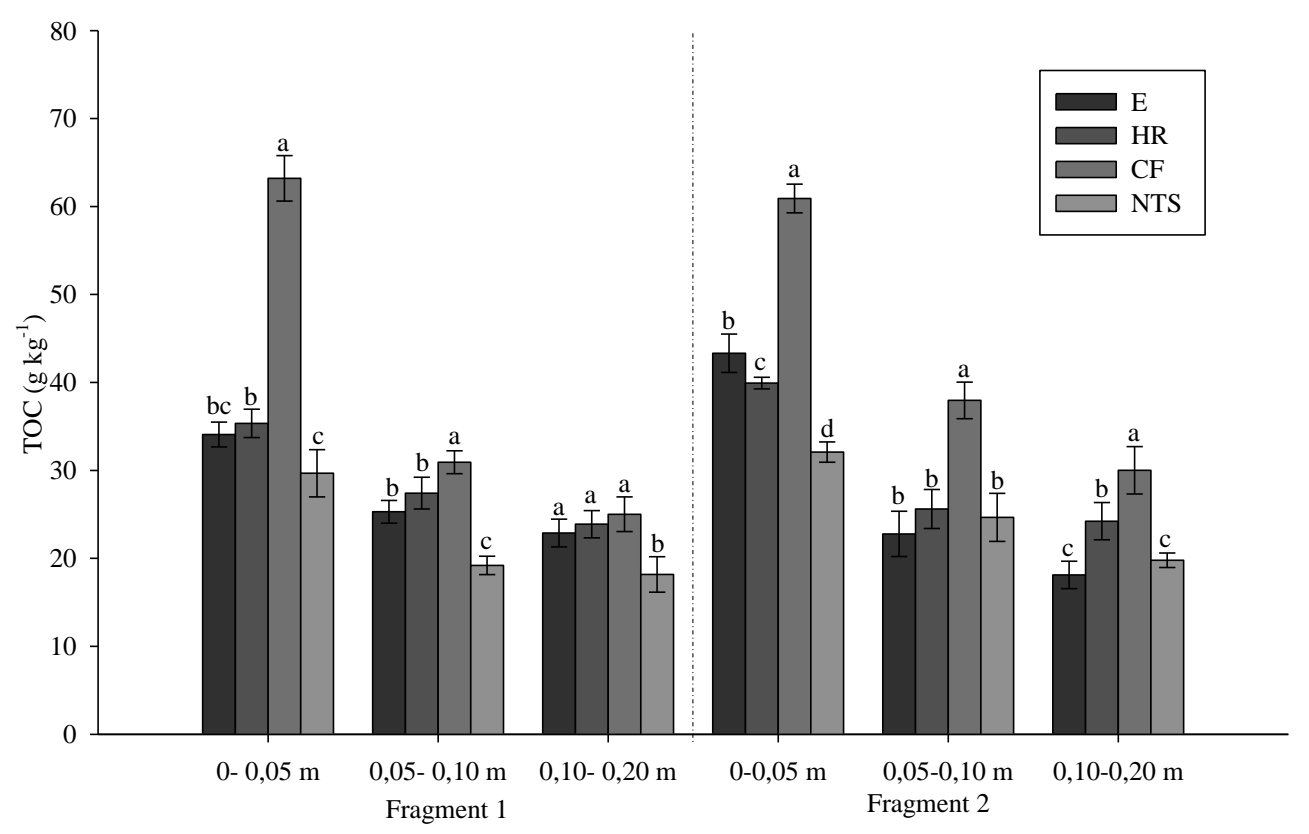

Figure 2. Total organic carbon (TOC) from the different collection points within and around fragments 1 and 2. Means followed by the same letter in the layer, for each fragment, do not differ statistically by the Tukey test (5\%). E: Fragment edge; HR: Half radius; CF: Center of the fragment; NTS: No-tillage system. Dashes on the bars represent the standard deviation of the data.

The higher levels of TOC in the CF point compared to E and HR is mainly due to the greater isolation of this point in relation to the external factors, indicating that the points near the edge suffer greater influence of fragmentation, mainly due to the higher incidence of light and microclimatic changes in these areas (Laurance et al., 1998). The highest contents presented by the internal points of the fragments compared to the NTS area is due to the greater contribution of litter in the most different forms (leaves, branches, fruits and thin roots), that is, a greater heterogeneity in the carbon/nitrogen ratio (C/N) (Matos et al., 2017), which maintains the flow of TOC and increases carbon stocks in these areas (Rosset et al., 2014; Freitas et al., 2018; Assunção et al., 2019).

On the other hand, the conversion of native areas into NTS ends up reducing the soil TOC, which, with the revolving, exposes the SOM to the oxidation process, increasing the emission of carbon dioxide $\left(\mathrm{CO}_{2}\right)$ into the atmosphere (Reinsch et al., 2018). These results corroborate those presented by Rosset et al. (2014; 2016; 2019b), Assunção et al. (2019) and Pereira and Neves (2007), who obtained higher levels of TOC in native forest areas, compared to areas of NTS with up to 22 years of conduction, in the same area, with the same type of soil and vegetation.

The highest levels of C-POM in the 0-0.05 m layer were found in E and CF points in Fragment 1, 13.2 and $12.1 \mathrm{~g} \mathrm{~kg}^{-1}$, respectively, and CF in Fragment 2, $19.5 \mathrm{~g} \mathrm{~kg}^{-1}$, differing from the other points (Table 4). The Points E, HR and CF do not undergo anthropic alterations, therefore presenting a higher conservation status, with constant deposition of organic material on the soil surface (Malchow et al., 2017), in addition to presenting greater diversity of plant species, different decomposition times and C/N ratio (Nascimento and Laurance, 2006), which favors the diversity of SOM, and consequent accumulation of particulate matter. 
Table 4. Carbon of particulate organic matter (C-POM) and mineral (C-MOM), percentage of carbon of particulate organic matter (POM) and mineral (MOM), carbon stock of particulate organic matter (StockPOM) and mineral (StockMOM) at different collection points within and around Fragments 1 and 2 of the Atlantic Forest biome.

\begin{tabular}{|c|c|c|c|c|c|c|c|c|c|c|c|c|}
\hline \multicolumn{7}{|c|}{ Fragment 1} & \multicolumn{6}{|c|}{ Fragment 2} \\
\hline & C-POM & C-MOM & POM & MOM & StockPOM & StockMOM & C-POM & C-MOM & POM & MOM & StockPOM & StockMOM \\
\hline & \multicolumn{2}{|c|}{$\mathrm{g} \mathrm{kg}^{-1}$} & \multicolumn{2}{|c|}{$\%$} & \multicolumn{2}{|c|}{$\mathrm{Mg} \mathrm{ha}^{-1}$} & \multicolumn{2}{|c|}{$\mathrm{g} \mathrm{kg}^{-1}$} & \multicolumn{2}{|c|}{$\%$} & \multicolumn{2}{|c|}{$\mathrm{Mg} \mathrm{ha}^{-1}$} \\
\hline \multicolumn{13}{|c|}{$0-0.05 \mathrm{~m}$} \\
\hline $\mathrm{E}$ & $13.2 \mathrm{a}$ & $20.8 \mathrm{c}$ & $38.9 \mathrm{a}$ & $61.1 \mathrm{c}$ & $4.7 \mathrm{a}$ & $7.4 \mathrm{c}$ & $15.3 b$ & $28.0 \mathrm{~b}$ & $35.7 \mathrm{a}$ & $64.5 b$ & $5.5 b$ & $10.0 \mathrm{~b}$ \\
\hline HR & $8.5 b$ & $26.9 b$ & $24.2 \mathrm{bc}$ & $75.8 \mathrm{ab}$ & $3.0 \mathrm{~b}$ & $9.5 b$ & $11.6 \mathrm{c}$ & $28.4 b$ & $29.0 \mathrm{~b}$ & $71.0 \mathrm{a}$ & $4.1 \mathrm{c}$ & $10.1 b$ \\
\hline $\mathrm{CF}$ & $12.1 \mathrm{a}$ & $51.1 \mathrm{a}$ & $19.1 \mathrm{c}$ & $80.9 \mathrm{a}$ & $4.3 \mathrm{a}$ & $18.4 \mathrm{a}$ & $19.5 \mathrm{a}$ & $41.4 \mathrm{a}$ & $32.1 \mathrm{ab}$ & 67.9ab & $7.0 \mathrm{a}$ & $14.8 \mathrm{a}$ \\
\hline NTS & $8.2 b$ & $21.4 \mathrm{bc}$ & $28.0 \mathrm{~b}$ & $72.0 \mathrm{~b}$ & $2.9 \mathrm{~b}$ & $7.6 b c$ & $10.9 \mathrm{c}$ & $21.2 \mathrm{c}$ & $33.9 \mathrm{a}$ & $66.0 \mathrm{~b}$ & $3.9 \mathrm{c}$ & $7.5 \mathrm{c}$ \\
\hline $\mathrm{CV}(\%)$ & 10.1 & 9.0 & 14.7 & 5.6 & 10.1 & 9.0 & 6.8 & 6.3 & 8.7 & 8.7 & 6.8 & 6.3 \\
\hline \multicolumn{13}{|c|}{$0.05-0.10 \mathrm{~m}$} \\
\hline $\mathrm{E}$ & $5.6 \mathrm{~b}$ & $19.6 \mathrm{~b}$ & $22.4 \mathrm{~b}$ & $77.6 \mathrm{a}$ & $2.4 \mathrm{~b}$ & $8.3 b$ & $10.1 \mathrm{ab}$ & $12.7 \mathrm{c}$ & $44.4 \mathrm{a}$ & $55.6 \mathrm{~b}$ & $4.1 \mathrm{ab}$ & $5.2 \mathrm{c}$ \\
\hline HR & $5.1 \mathrm{~b}$ & $22.3 \mathrm{ab}$ & $18.5 b$ & $81.4 \mathrm{a}$ & $2.1 \mathrm{~b}$ & $9.4 \mathrm{ab}$ & $8.1 b c$ & $17.5 b$ & $31.7 \mathrm{~b}$ & $68.2 \mathrm{a}$ & $3.3 \mathrm{bc}$ & $7.1 \mathrm{~b}$ \\
\hline $\mathrm{CF}$ & $7.0 \mathrm{a}$ & $24.0 \mathrm{a}$ & $22.4 b$ & $77.5 \mathrm{a}$ & $2.9 \mathrm{a}$ & $10.1 \mathrm{a}$ & $10.7 \mathrm{a}$ & $27.2 \mathrm{a}$ & $28.1 b$ & $70.9 a$ & $4.4 \mathrm{a}$ & $11.2 \mathrm{a}$ \\
\hline NTS & $5.3 b$ & $13.9 \mathrm{c}$ & $27.7 \mathrm{a}$ & $72.3 b$ & $2.2 \mathrm{~b}$ & $5.9 \mathrm{c}$ & $7.5 \mathrm{c}$ & $17.1 \mathrm{~b}$ & $30.7 \mathrm{~b}$ & $69.3 \mathrm{a}$ & $3.1 \mathrm{c}$ & $7.0 \mathrm{~b}$ \\
\hline $\mathrm{CV}(\%)$ & 10.3 & 7.1 & 10.6 & 3.1 & 10.3 & 7.1 & 12.5 & 9.5 & 9.2 & 4.7 & 12.5 & 9.5 \\
\hline \multicolumn{13}{|c|}{$0.10-0.20 \mathrm{~m}$} \\
\hline $\mathrm{E}$ & $3.0 \mathrm{~b}$ & $19.8 \mathrm{a}$ & $13.3 \mathrm{a}$ & $86.7 \mathrm{a}$ & $2.6 \mathrm{~b}$ & $17.0 \mathrm{a}$ & $6.3 \mathrm{ab}$ & $11.8 \mathrm{c}$ & $34.9 \mathrm{a}$ & $65.1 \mathrm{~b}$ & $5.1 \mathrm{ab}$ & $9.7 \mathrm{c}$ \\
\hline HR & $3.6 \mathrm{a}$ & $20.3 \mathrm{a}$ & $15.0 \mathrm{a}$ & $85.1 \mathrm{a}$ & $3.1 \mathrm{ab}$ & $17.4 \mathrm{a}$ & $5.5 \mathrm{ab}$ & $18.7 b$ & $22.8 \mathrm{~b}$ & $77.2 \mathrm{a}$ & $4.5 \mathrm{ab}$ & $15.3 b$ \\
\hline $\mathrm{CF}$ & $3.9 \mathrm{a}$ & $21.1 \mathrm{a}$ & $15.7 \mathrm{a}$ & $84.3 \mathrm{a}$ & $3.7 \mathrm{a}$ & $18.1 \mathrm{a}$ & $6.4 \mathrm{a}$ & $23.6 \mathrm{a}$ & $21.6 \mathrm{~b}$ & $78.4 \mathrm{a}$ & $5.2 \mathrm{a}$ & $19.3 \mathrm{a}$ \\
\hline NTS & $3.1 \mathrm{ab}$ & $15.1 b$ & $17.4 \mathrm{a}$ & $82.6 a$ & $2.7 \mathrm{ab}$ & $12.9 b$ & $4.6 \mathrm{~b}$ & $15.2 \mathrm{bc}$ & $22.9 \mathrm{~b}$ & $77.0 \mathrm{a}$ & $3.7 \mathrm{~b}$ & $12.4 \mathrm{bc}$ \\
\hline $\mathrm{CV}(\%)$ & 12.1 & 9.6 & 17.4 & 3.1 & 12.0 & 9.6 & 15.1 & 12.2 & 17.8 & 6.1 & 15.1 & 12.2 \\
\hline
\end{tabular}

Means followed by the same letter in the columns for each fragment and layer do not differ statistically by the Tukey test (5\%). E: Fragment edge; HR: Half radius; CF: Center of the fragment; NTS: No-tillage system; CV (\%): coefficient of variation. 
In the 0.10-0.20 m layer of fragment 1, the lowest C-POM contents were found in Point E, $3.0 \mathrm{~g} \mathrm{~kg}^{-1}$, and in the surrounding NTS area, with $3.1 \mathrm{~g} \mathrm{~kg}^{-1}$. In Fragment 2, the lowest level of C-POM was found in the NTS area, $4.6 \mathrm{~g} \mathrm{~kg}^{-1}$ (Table 4). These results suggest that the low plant heterogeneity of the NTS, since it does not have a diversified rotation (Boddey et al., 2010), may compromise the dynamics of particulate matter entry into the soil over the years of cultivation (Ferreira et al., 2018).

The highest C-MOM contents were found in the CF point in the 0-0.05 m layer in both fragments, reaching 51.1 and $41.4 \mathrm{~g} \mathrm{~kg}^{-1}$ in Fragments 1 and 2, respectively. In Fragment 2, the $\mathrm{CF}$ point presented higher contents in all evaluated layers (Table 4). In the layer 0.10-0.20 $\mathrm{m}$ in Fragment 1, E, HR and CF points presented the highest C-MOM contents, differing from the NTS area. These results are due to the higher levels of TOC in the CF point (Figure 2). In addition, not revolving the soil allows humification processes to occur completely, promoting the stabilization of SOM (Lal, 2018), and consequent carbon accumulation in the most recalcitrant fractions.

The lowest levels of C-MOM were observed in the 0.10-0.20 m layer, in the NTS area around Fragment 1, and in point E and NTS area of Fragment 2 (Table 4). The fact that only soybean/corn succession has been cultivated for several years in the areas of NTS, also influences on the lower carbon content of this fraction, because the greater diversity of plant residues left in systems with greater crop diversity considerably increases the entry of SOM in the most labile fraction of carbon and, consequently, over time, of the more recalcitrant fractions of C (Faccin et al., 2017), when compared to systems with less diversity (Boddey et al., 2010; Campos et al., 2011).

The percentage of POM and MOM, which shows the representativeness of these fractions in relation to TOC, varied from 13.3 to $38.9 \%$ for POM, and from 61.1 to $86.7 \%$ for MOM in all points and layers evaluated in Fragment 1. In Fragment 2, this variation was from $21.6 \%$ to 44.4, and from 55.6\% to $78.4 \%$, respectively, for POM and MOM (Table 4). The high representativeness of MOM is associated with soil granulometry of the studied areas, since the most stable soil organic matter binds to the colloidal fraction (Cambardella and Elliott, 1992), which represents most of the soil granulometry of the study areas. In addition, the tropical climate plays a fundamental role in this behavior of distribution of the granulometric fractions of the POM, because it acts directly in the humification process of the SOM, converting the POM into MOM in a faster process than in temperate climate regions (Gmach et al., 2018), providing greater representativeness of MOM in relation to POM. This fact was also highlighted by Rosset et al. (2019b) in the same area of this study, also in native areas and managed under NTS.

It is important to highlight that the percentage representativeness of the fractions had a similar pattern in both fragments studied (Table 4), where the percentage of POM decreased, and of MOM increased as a function of the increase in depth. This occurs mainly due to the greater contribution of particulate matter to the soil surface, which associated with nonrevolving, transforms this labile material into recalcitrant along the profile (Lal, 2018; Reinsch et al., 2018).

The highest StockPOM and StockMOM were observed in the CF points of both fragments (Table 4), corroborating the higher levels of TOC in this same point (Figure 2). Specifically, in Fragment 1, in the 0-0.05 m layer, the StockPOM was similar between the E and CF points, with values of 4.7 and $4.3 \mathrm{Mg} \mathrm{ha}^{-1}$, respectively. In Fragment 2, in Point CF, the StockPOM presented the highest value, $6.7 \mathrm{Mg} \mathrm{ha}^{-1}$, in the 0-0.05 m layer, differing from the other points.

In Fragment 1, the CF point presented StockMOM of $18.4 \mathrm{Mg} \mathrm{ha}^{-1}$, differing from the other points in the 0-0.05 m layer. In Fragment 2, the StockMOM was $14.7 \mathrm{Mg} \mathrm{ha}^{-1}, 11.2 \mathrm{Mg}$ $\mathrm{ha}^{-1}$ and 19.3 $\mathrm{Mg} \mathrm{ha}^{-1}$ in layers 0-0.05, 0.05-0.10 and 0.10-0.20 m, respectively, in the CF Point, higher than all other points studied (Table 4). Lower values of StockPOM and StockMOM in the areas of NTS around the two studied fragments are notorious, especially in the 0-0.05 m layer. 
The highest StockPOM and StockMOM, mainly in the CF Point (Table 4) are due to the highest levels of TOC (Figure 2), C-POM and C-MOM (Table 4). Because it is more isolated in relation to the other points, the CF Point presents greater diversity of forest strata and constant litter deposition (Malchow et al., 2017), which allows biogeochemical processes to be completed (Smith, 2012; Gmach et al. 2018), thus enabling to find high stocks of both fractions (Melo et al., 2016). In a study in a system with permanent pasture, regeneration and native forest in the Atlantic Forest biome, Nogueira et al. (2016) also found higher stocks of POM and MOM in the native forest area compared to different production systems, as similarly evidenced by Rosset et al. (2019b) in the same edaphoclimatic conditions and management systems.

The Points E, HR and areas NTS around both fragments presented lower CSI values in relation to the reference point $(\mathrm{CF})$. The lowest values were observed in the NTS areas in the layer 0-0.05 m, 0.5 and 0.5 around Fragments 1 and 2, respectively (Table 5). These results indicate that none of the points evaluated, in both fragments, presented carbon storage higher than the inner point, as also reported for the TOC contents (Figure 2), because all values of this variable were lower than 1.0 (Table 5).

Table 5. Carbon stock index (CSI), SOM lability (L), lability index (LI) and carbon management index (CMI) of the different collection points, within and around Fragments 1 and 2.

\begin{tabular}{|c|c|c|c|c|c|c|c|c|}
\hline & \multicolumn{4}{|c|}{ Fragment 1} & \multicolumn{4}{|c|}{ Fragment 2} \\
\hline & CSI & $\mathrm{L}$ & LI & CMI & CSI & $\mathrm{L}$ & LI & CMI \\
\hline \multicolumn{9}{|c|}{$0-0.05 \mathrm{~m}$} \\
\hline $\mathrm{E}$ & $0.5 b$ & $0.6 \mathrm{a}$ & $2.7 \mathrm{a}$ & $147.9 \mathrm{a}$ & $0.7 b$ & $0.5 \mathrm{a}$ & $1.2 \mathrm{a}$ & $83.4 b$ \\
\hline HR & $0.5 b$ & $0.3 b$ & $1.3 b$ & $75.5 b$ & $0.6 \mathrm{~b}$ & $0.4 b$ & $0.9 \mathrm{~b}$ & $56.9 \mathrm{c}$ \\
\hline $\mathrm{CF}$ & $1.0 \mathrm{a}$ & $0.2 b$ & $1.0 \mathrm{~b}$ & $100.0 \mathrm{~b}$ & $1.0 \mathrm{a}$ & $0.5 \mathrm{ab}$ & $1.0 \mathrm{ab}$ & $100.0 \mathrm{a}$ \\
\hline NTS & $0.5 \mathrm{c}$ & $0.4 \mathrm{~b}$ & $1.6 \mathrm{~b}$ & $76.7 \mathrm{~b}$ & $0.5 \mathrm{c}$ & $0.5 \mathrm{ab}$ & $1.1 \mathrm{ab}$ & $57.3 \mathrm{c}$ \\
\hline $\mathrm{CV}(\%)$ & 3.8 & 21.8 & 21.6 & 19.1 & 4.4 & 10.8 & 11.4 & 20.0 \\
\hline \multicolumn{9}{|c|}{$0.05-0.10 \mathrm{~m}$} \\
\hline $\mathrm{E}$ & $0.8 \mathrm{~b}$ & $0.3 b$ & $1.0 \mathrm{ab}$ & $82.1 \mathrm{ab}$ & $0.6 \mathrm{~b}$ & $0.8 \mathrm{a}$ & $2.1 \mathrm{a}$ & $123.6 \mathrm{a}$ \\
\hline HR & $0.9 \mathrm{~b}$ & $0.2 \mathrm{~b}$ & $0.8 b$ & $69.3 b$ & $0.7 b$ & $0.5 b$ & $1.2 \mathrm{~b}$ & $82.3 b$ \\
\hline $\mathrm{CF}$ & $1.0 \mathrm{a}$ & $0.3 \mathrm{~b}$ & $1.0 \mathrm{~b}$ & $100.0 \mathrm{a}$ & $1.0 \mathrm{a}$ & $0.4 b$ & $1.0 \mathrm{~b}$ & $100.0 \mathrm{ab}$ \\
\hline NTS & $0.6 \mathrm{c}$ & $0.4 \mathrm{a}$ & $1.3 \mathrm{a}$ & $82.5 \mathrm{ab}$ & $0.6 b$ & $0.4 b$ & $1.1 b$ & $75.4 b$ \\
\hline $\mathrm{CV}(\%)$ & 5.8 & 13.6 & 15.8 & 11.6 & 7.6 & 13.7 & 21.2 & 18.4 \\
\hline \multicolumn{9}{|c|}{$0.10-0.20 \mathrm{~m}$} \\
\hline $\mathrm{E}$ & $0.9 \mathrm{a}$ & $0.1 \mathrm{a}$ & $0.8 \mathrm{a}$ & $76.1 \mathrm{a}$ & $0.6 \mathrm{c}$ & $0.5 \mathrm{a}$ & $2.0 \mathrm{a}$ & $122.9 \mathrm{a}$ \\
\hline HR & $0.9 \mathrm{a}$ & $0.2 \mathrm{a}$ & $0.9 \mathrm{a}$ & $90.5 \mathrm{a}$ & $0.8 b$ & $0.3 b$ & $1.1 \mathrm{~b}$ & $89.1 \mathrm{ab}$ \\
\hline $\mathrm{CF}$ & $1.0 \mathrm{a}$ & $0.2 \mathrm{a}$ & $1.0 \mathrm{a}$ & $100.0 \mathrm{a}$ & $1.0 \mathrm{a}$ & $0.3 b$ & $1.0 \mathrm{~b}$ & $100.0 \mathrm{ab}$ \\
\hline NTS & $0.7 \mathrm{~b}$ & $0.2 \mathrm{a}$ & $1.2 \mathrm{a}$ & $83.2 \mathrm{a}$ & $0.7 b c$ & $0.3 b$ & $1.1 b$ & $71.9 \mathrm{~b}$ \\
\hline $\mathrm{CV}(\%)$ & 9.5 & 21.7 & 27.4 & 16.5 & 11.5 & 25.5 & 31.8 & 22.5 \\
\hline
\end{tabular}

Means followed by the same letter in the columns for each fragment and layer do not differ statistically by the Tukey test (5\%). E: Fragment edge; HR: Half radius; CF: center of the fragment; NTS: No-tillage system; CV $(\%)$ : coefficient of variation.

These changes in carbon stock in E and HR points and in the NTS area compared to the reference suggest that the conversion of natural areas into production systems can reduce soil carbon storage (Rosset et al., 2014; Reis et al., 2016). In addition, forest fragmentation reduced 
the carbon stock in the points near the edge, possibly due to the changes it causes, with decreased TOC (Figure 2), by increasing luminosity and temperature (Camargo and Kapos, 1995), higher incidence of winds (Laurance et al., 1998), which can accelerate the oxidation process of SOM, releasing greater amounts of carbon dioxide into the atmosphere (Lal, 2018; Sperow, 2018; Magalhães et al., 2016). These results from the points near the edge contrast to those presented by Barros and Fearnside (2016), who found an increase in carbon stock on the edges of forest fragments in the Amazon.

The $\mathrm{L}$ values were below the unit in all points and layers evaluated, which indicates a predominance of $\mathrm{C}-\mathrm{MOM}$ in relation to the $\mathrm{C}-\mathrm{POM}$ (Table 5). The E point presented the highest $\mathrm{L}$ value (0.6), in the layer $0-0.05 \mathrm{~m}$, in fragment 1 , and in the layer $0.10-0.20 \mathrm{~m}$ there was no difference between the points, varying from 0.1 to 0.2 (Table 5). In Fragment 2, Point E presented the highest $\mathrm{L}$ values in all evaluated layers, $0.5 ; 0.8$ and 0.5 , for layers $0-0.05,0.05$ 0.10 and $0.10-0.20 \mathrm{~m}$. These results generally indicate low $\mathrm{L}$ of the $\mathrm{C}$ in these areas, because $\mathrm{L}$ represents the relationship between C-POM and C-MOM, which makes this variable an important indicator of soil quality, given the importance of balance between these fractions, for maintenance of $\mathrm{C}$ in the soil over time (Benbi et al., 2015; Jha, 2017).

The LI showed the same pattern of L values, indicating higher values in Point $\mathrm{E}$ of both fragments evaluated in the 0-0.05 m layer, surpassing the LI of the reference (CF). The CMI, which expresses the evaluation of SOM in quantitative and qualitative terms, presented higher values than the reference point (CF) only in Point $\mathrm{E}$ (147.9) in the layer 0-0.05 $\mathrm{m}$ in Fragment 1 , and the points evaluated did not present differences in the layer 0.10-0.20 $\mathrm{m}$ (Table 5). In Fragment 2, Point E presented values similar to those of CF in the 0.05-0.10 $\mathrm{m}$ and $0.10-0.20$ $\mathrm{m}$ layers (Table 5). This increase in CMI in Point $\mathrm{E}$ may be related to the greater litter intake that forest fragments present in the extremities (Malchow et al., 2017; Nascimento and Laurance, 2006; Barros and Fearnside, 2016), and also due to the higher values of L and consequently LI (Table 5).

In both fragments studied, CMI values lower than the reference area were observed in the surrounding NTS areas (Table 5). These results demonstrate that the modification caused by the conversion of natural areas may compromise soil quality (Rosset et al., 2019b), mainly in surface layers, affecting the quality of SOM due to the low diversity of species in the soybean/corn succession over the years of cultivation, which directly influences the physical quality (Sales et al., 2018), chemistry (Souza et al., 2018) and the biological activity (Borges et al., 2016) of the soil over the years of cultivation.

Forms of soil management that provide greater floristic heterogeneity and, consequently, higher CMI values, will act directly on the mentioned attributes, improving water infiltration (Souza et al., 2017) soil aggregation (Obour et al., 2018), porosity (Lal, 2018), among other quality indicators. Gazolla et al. (2015) obtained in their study a CMI value of 48.1 for layer 0$0.05 \mathrm{~m}$ in NTS with 10 years of implantation, compared to an area of native vegetation. Souza et al. (2018) studying NTS chronosequence in clay soil, obtained CMI of 112, 128 and 139 for NTS with 7, 11 and 16 years of implantation.

In Fragments 1 and 2, the $\mathrm{CF}$ point showed the highest $\mathrm{C}-\mathrm{CO}_{2}$ emission on the 1 st day after incubation, 14.1 and $12.1 \mathrm{mg}$ of $\mathrm{C}-\mathrm{CO}_{2}$ in $50 \mathrm{~g}$ of soil, respectively. The NTS areas presented the lowest emissions in the first evaluation, 5.5 and $5.9 \mathrm{mg}$ of $\mathrm{C}-\mathrm{CO}_{2}$ in $50 \mathrm{~g}$ of soil, respectively (Figures $3 \mathrm{a}, \mathrm{b}$ ). The points with the highest emissions on the 1st day were also the ones that presented the highest levels of TOC (Figure 2) and C-POM (Table 4) in the 0-0.05 m layer. This higher initial emission of $\mathrm{C}-\mathrm{CO}_{2}$ occurs when microbial activity is stimulated by the availability of labile organic residues, in this case C-POM, which accelerates the decomposition of SOM (Hurisso et al., 2016; 2018; Wade et al., 2018), having a relationship between higher levels of TOC (Figure 2) and C-POM (Table 4) with the highest C-CO $\mathrm{CO}_{2}$ emissions (Figures 2 a, b). 
In Fragments 1 and 2, between the 4th and 6th day, and between the 13th and 21st day of incubation, $\mathrm{C}-\mathrm{CO}_{2}$ emission peaks were evident (Figures $3 \mathrm{a}, \mathrm{b}$ ). These emission peaks occur due to the death of part of the microorganisms that serve as food for the remnants, generating emission peaks after the decreases (Gonçalves et al., 2002), an effect known as prining (Ghosh et al., 2018; Kuzyakov et al., 2000). In both fragments, from the 25th day on, the emission began to stabilize (Figures $3 \mathrm{a}, \mathrm{b}$ ), i.e., no $\mathrm{C}-\mathrm{CO}_{2}$ emission peaks were observed. This stabilization in $\mathrm{C}-\mathrm{CO}_{2}$ emission occurs by reducing the availability of labile organic materials readily available to microbial attack. This pattern was also observed by Loss et al. (2013) in Goiás and Rosset et al. (2019b) in Paraná, studying the emission of mineralizable carbon in Latosol in different management systems.
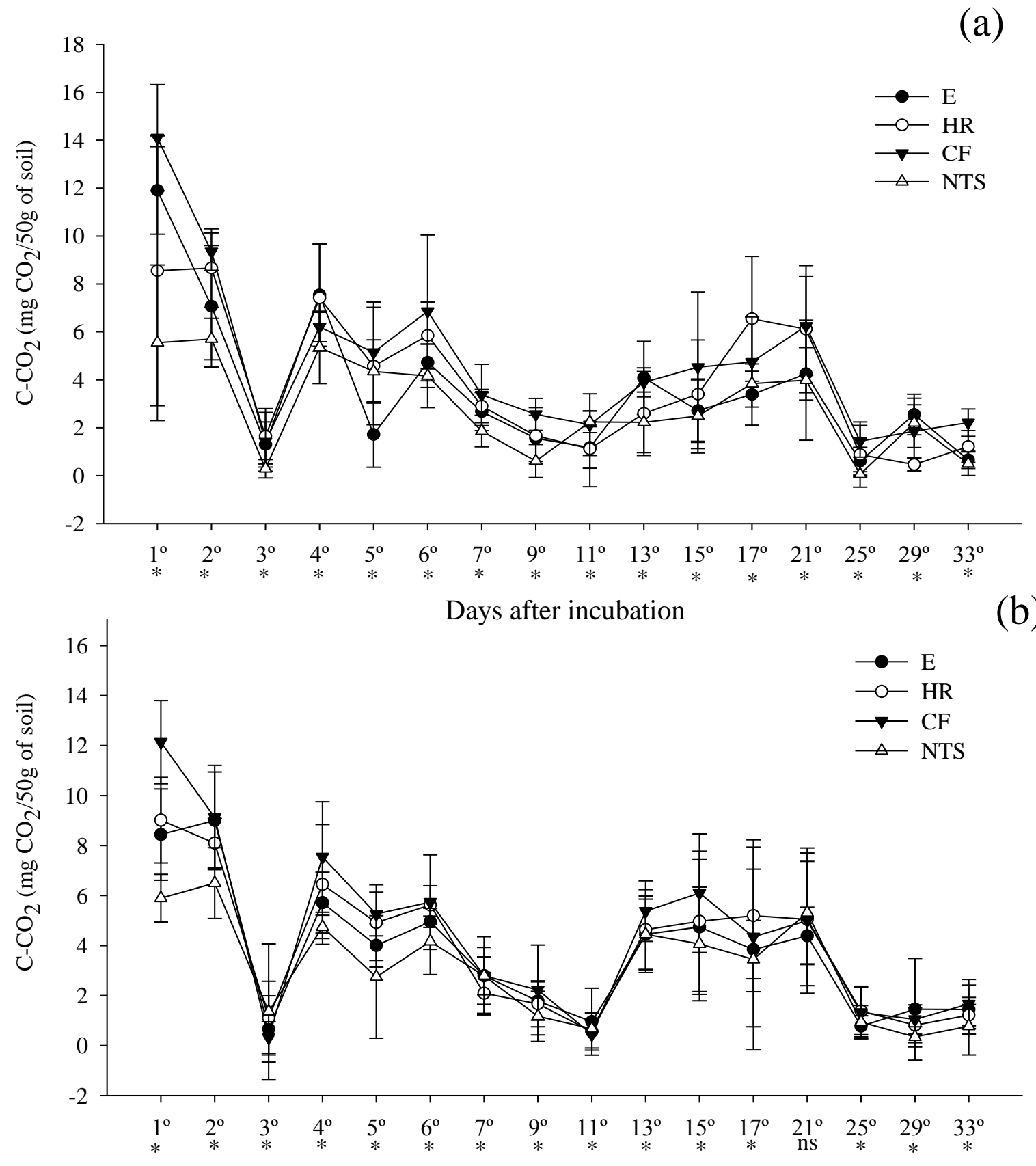

(b)

Days after incubation

Figure 3. Mineralizable carbon of the soil incubated in the laboratory until the 33rd day of the different collection points within and around Fragments 1 (a) and 2 (b). * = Significant by Tukey test at $5 \%$; ns $=$ Not significant by Tukey test at $5 \%$. 
The highest accumulations of $\mathrm{C}-\mathrm{CO}_{2}$ after the 33rd day of incubation were observed in the $\mathrm{CF}, 75.7$ and $69.7 \mathrm{mg} \mathrm{CO}$ in $50 \mathrm{~g}$ of soil in Fragments 1 and 2, respectively (Figure 4). The results also show that both fragments present a pattern of gradual total emission reduction when moving from the CF Point to the E, i.e., lower soil microbial activity is observed. The highest accumulations of total $\mathrm{C}-\mathrm{CO}_{2}$ occurred exactly in the points where the highest levels of TOC (Figure 2) and the highest levels of C-POM (Table 4) were obtained, ratifying the pattern also presented by Wade et al. (2018) and Rosset et al. (2019b).

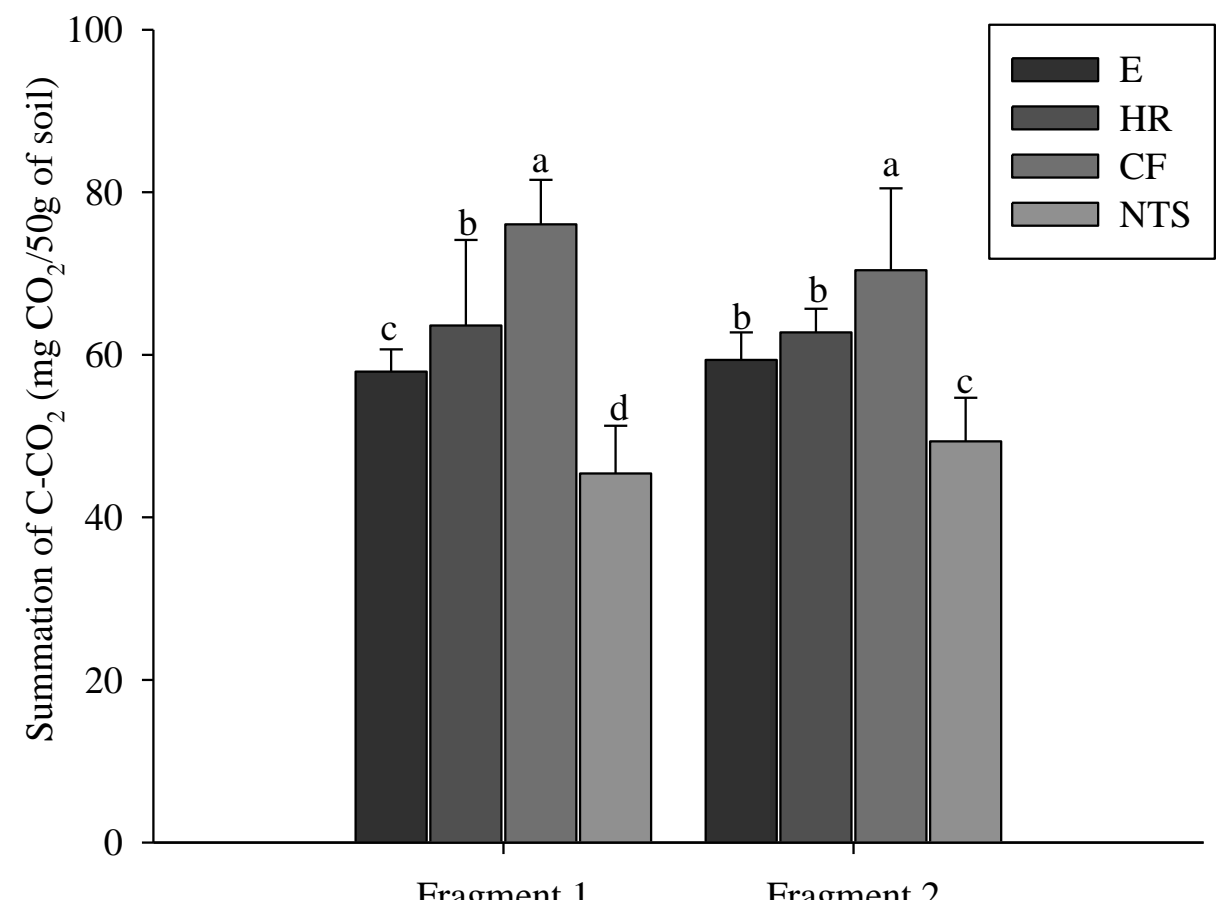

Fragment 1

Fragment 2

Figure 4. Summation of $\mathrm{C}-\mathrm{CO}_{2}(\mathrm{mg} \mathrm{CO} / 50 \mathrm{~g}$ of soil), during the incubation period of the soil in the laboratory, in the different collection points within and around Fragments 1 and 2. Means with the same letter do not differ statistically by the Tukey test (5\%). E: Fragment edge; HR: Half radius; CF: Center of the fragment; NTS: No-tillage system. Dashes on the bars represent the standard deviation of the data.

The NTS areas around the fragments presented the lowest total values of $\mathrm{C}-\mathrm{CO}_{2}$ emission, 45.6 and $49.9 \mathrm{mg} \mathrm{CO}$ in $50 \mathrm{~g}$ of soil, which represents $39.8 \%$ and $28.3 \%$ reduction for the highest emission points, for Fragments 1 and 2, respectively (Figure 4). In turn, the lowest levels of TOC (Figure 2) and C-POM (Table 4) were also observed in the areas of NTS, indicating the direct relationship of the organic matter of easier decomposition with the highest accumulations of total $\mathrm{C}-\mathrm{CO}_{2}$, and consequent microbiological activity (Barreto et al., 2009). Loss et al. (2013) and Rosset et al. (2019b) observed lower values of $\mathrm{C}^{-\mathrm{CO}_{2}}$ accumulation in NTS, compared to the area of native vegetation. The results contrast with those presented by Benbi et al. (2015), in which the managed areas showed higher evolution of $\mathrm{C}-\mathrm{CO}_{2}$, in relation to areas under native vegetation, after 32 days of incubation.

\section{CONCLUSIONS}

The levels of total organic carbon and particulate fraction of soil organic matter from the internal points of the forest fragments were higher than those of the no-tillage system areas around them, indicating that the conversion of native areas into cultivation systems compromises quantitatively and qualitatively the organic fraction of the soil. 
The carbon management index showed a distinct pattern among the studied fragments, and was not sensitive to identify internal changes in forest fragments.

The mineralizable carbon analysis indicated that the conversion of native areas into notillage systems, causes less microbial activity, also evidencing an increase in microbial activity when entering the most peripheral areas to the more central areas of the forest fragment in the Atlantic Forest biome.

\section{ACKNOWLEDGMENTS}

We thank Coordenação de Aperfeiçoamento de Pessoal de Nível Superior (CAPES), for granting the master's scholarship to the first author. Universidade Estadual de Mato Grosso do Sul through the Programa de Pós-Graduação em Agronomia - Produção Vegetal. We also thank the rural owners who made their areas available for soil sample collections.

\section{REFERENCES}

ASSUNÇÃO, S. A.; PEREIRA, M. G.; ROSSET, J. S.; BERBARA, R. L. L.; GARCÍA, A. C. Carbon input and the structural quality of soil organic matter as a function of agricultural management in a tropical climate region of Brazil. Science of the Total Environment, v. 658, p. 901-911, 2019. https://doi.org/10.1016/j.scitotenv.2018.12.271

BARRETO, R. C.; MADARI, B. E.; MADDOCK, J. E.; MACHADO, P. L.; TORRES, E.; FRANCHINI, J.; COSTA, A. R. The impact of soil management on aggregation, carbon stabilization and carbon loss as $\mathrm{CO}_{2}$ in the surface layer of a Rhodic Ferralsol in Southern Brazil. Agriculture, Ecosystems \& Environment, v. 132, n. 3-4, p. 243-251, 2009. https://doi.org/10.1016/j.agee.2009.04.008

BARROS, H. S.; FEARNSIDE, P. M. Soil carbon stock changes due to edge effects in central Amazon forest fragments. Forest Ecology and Management, v. 379, p. 30-36, 2016. https://doi.org/10.1016/j.foreco.2016.08.002

BENBI, D. K.; BRAR, K.; TOOR, A. S.; SINGH, P. Total and labile pools of soil organic carbon in cultivated and undisturbed soils in northern India. Geoderma, v. 237, p. 149158, 2015. https://doi.org/10.1016/j.geoderma.2014.09.002

BHERING, S. B.; SANTOS, H. G.; MANZATTO, C. V. et al. Mapa de solos do Estado do Paraná. Rio de Janeiro: Embrapa, 2007, 73p.

BLAIR, G. J.; LEFROY, R. D. B.; LISLE, L. Soil carbon fractions based on their degree of oxidation, and the development of a carbon management index for agricultural systems. Australian Journal of Agricultural Research, v. 46, n. 7, p. 1459-1466, 1995. https://doi.org/10.1071/AR9951459

BODDEY, R. M.; JANTALIA, C. P.; CONCEICÃO, P. C.; ZANATTA, J. A.; BAYER, C.; MIELNICZUK, J.; DIECKOW, J.; SANTOS, H. P.; DENARDIN, J. E.; AITA, C.; GIACOMINI, S. J.; ALVES, B. J. R.; URQUIAGA S. Carbon accumulation at depth in Ferralsols under zero-till subtropical agriculture. Global Change Biology, v. 16, n. 2, p. 784-795, 2010. https://doi.org/10.1111/j.1365-2486.2009.02020

BORGES, C.; RIBEIRO, B. T.; WENDLING, B.; CABRAL, D. A. Agregação do solo, carbono orgânico e emissão de $\mathrm{CO}_{2}$ em áreas sob diferentes usos no Cerrado, região do Triângulo Mineiro. Revista Ambiente \& Água, v. 10, n. 3, p. 661-675, 2016. https://doi.org/10.4136/ambi-agua.1573 
CAMARGO, J. L. C.; KAPOS, V. Complex edge effects on soil moisture and microclimate in central Amazonian forest. Journal of Tropical Ecology, v. 11, n. 2, p. 205-221, 1995. https://doi.org/10.1017/S026646740000866X

CAMBARDELLA, C. A.; ELLIOTT, E. T. Particulate soil organic-matter changes across a grassland cultivation sequence. Soil Science Society of America Journal, v. 56, n. 3, p. 777-783, 1992. http://dx.doi.org/10.2136/sssaj1992.03615995005600030017x

CAMPOS, B. H. C. D.; AMADO, T. J. C.; BAYER, C.; NICOLOSO, R. D. S.; FIORIN, J. E. Carbon stock and its compartments in a subtropical oxisol under long-term tillage and crop rotation systems. Revista Brasileira de Ciência do Solo, v. 35, n. 3, p. 805-817, 2011. https://doi.org/10.1590/S0100-06832011000300016

CAMPOS, J. B.; SILVEIRA FILHO, L. Série Ecossistemas Paranaenses - Floresta Estacional Semidecidual. Curitiba: Governo do Estado do Paraná, 2010. 8p.

CAVIGLIONE, J. H.; KIIHL, L. R. B.; CARAMORI, P. H.; OLIVEIRA, D. Cartas climáticas do Paraná. Londrina: IAPAR, 2000. CD-ROM.

CLAESSEN, M. E. C. Manual de métodos de análise de solo. 2. ed. Rio de Janeiro: Embrapa, 1997. $212 \mathrm{p}$.

FACCIN, F. C.; MARCHETTI, M. E.; SERRA, A. P.; ENSINAS, S. C. Frações granulométricas da matéria orgânica do solo em consórcio de milho safrinha com capimmarandu sob fontes de nitrogênio. Pesquisa Agropecuária Brasileira, v. 51, n. 12, p. 2000-2009, 2017. https://doi.org/10.1590/s0100-204x2016001200011

FERREIRA, A. O.; SÁ, J. C. M; LAL, R.; TIVET, F.; BRIEDIS, C.; INAGAKI, T. M.; ROMANIW, J. Macroaggregation and soil organic carbon restoration in a highly weathered Brazilian Oxisol after two decades under no-till. Science of the Total $\begin{array}{lllll}\text { Environment, } & \text { v. } & 621, & \text { p. } & 1559-1567,\end{array}$ https://doi.org/10.1016/j.scitotenv.2017.10.072

FERREIRA, C. R.; SILVA NETO, E. C.; PEREIRA, M. G.; GUEDES, J. N.; ROSSET, J. S.; ANJOS, L. H. C. Dynamics of soil aggregation and organic carbon fractions over 23 years of no-till management. Soil \& Tillage Research, v. 198, p. 1-9, 2020. https://doi.org/10.1016/j.still.2019.104533

FREITAS, L.; OLIVEIRA, I. A.; CASAGRANDE, J. C.; SILVA, L. S.; CAMPOS, M. C. C. Estoque de carbono de Latossolos em sistemas de manejo natural e alterado. Ciência Florestal, v. 28, n. 1, p. 228-239, 2018. https://dx.doi.org/10.5902/1980509831575

GAZOLLA, P. R.; GUARESCHI, R. F.; PERIN, A., PEREIRA, M. G.; ROSSI, C. Q. Frações da matéria orgânica do solo sob pastagem, sistema plantio direto e integração lavourapecuária. Semina: Ciências Agrárias, v. 36, n. 2, p. 693-704, 2015. https://doi.org/10.5433/1679-0359

GHOSH, A.; BHATTACHARYYA, R.; MEENA, M. C.; DWIVEDI, B. S.; SINGH, G.; AGNIHOTRI, R.; SHARMA, C. Long-term fertilization effects on soil organic carbon sequestration in an Inceptisol. Soil \& Tillage Research, v. 77, p. 134-144, 2018. https://doi.org/10.1016/j.still.2017.12.006

GMACH, M. R.; DIAS, B. O.; SILVA, C. A.; NÓBREGA, J. C.; LUSTOSA-FILHO, J. F.; SIQUEIRA-NETO, M. Soil organic matter dynamics and land-use change on Oxisols in the Cerrado, Brazil. Geoderma Regional, v. 14, p. 1-8, 2018. https://doi.org/10.1016/j.geodrs.2018.e00178 
GONÇALVES, A. S.; MONTEIRO, M. T.; GUERRA, J. G. M. DE-POLLI, H. Biomassa microbiana em amostras de solos secadas ao ar e reumedecidas. Pesquisa Agropecuária Brasileira, v. 37, n. 5, p. 651-658, 2002. https://doi.org/10.1590/S0100204X2002000500010

HURISSO, T. T.; CULMAN, S. W.; HORWATH, W. R.; WADE, J.; CASS, D.; BENISTON, J. W.; LUCAS, S. T. Comparison of permanganate-oxidizable carbon and mineralizable carbon for assessment of organic matter stabilization and mineralization. Soil Science Society of America Journal, v. 80, n. 5, p. 1352-1364, 2016. https://doi.org/10.2136/sssaj2016.04.0106

HURISSO, T. T.; CULMAN, S. W.; ZONE, P.; SHARMA, S. Absolute values and precision of emerging soil health indicators as affected by soil sieve size. Communications in Soil Science and Plant Analysis, v. 49, n. 15, p. 1934-1942, 2018. https://doi.org/10.1080/00103624.2018.1492597

JHA, P.; VERMA, S.; LAL, R.; EIDSON, C.; DHERI, G. S. Natural 13C abundance and soil carbon dynamics under long-term residue retention in a no-till maize system. Soil Use and Management, v. 33, n. 1, p. 90-97, 2017. https://doi.org/10.1111/sum.12323

KAPOS, V. Effects of isolation on the water status of forest patches in the Brazilian Amazon. $\begin{array}{lllllllll}\text { Journal of Tropical Ecology, v. } & \text { 5, n. 2, p. } & \text { 173-185, }\end{array}$ https://doi.org/10.1017/S0266467400003448

KUZYAKOV, Y.; FRIEDEL, J. K.; STAHR, K. Review of mechanisms and quantification of priming effects. Soil Biology and Biochemistry, v. 32, n. 11-12, p. 1485-1498, 2000. https://doi.org/10.1016/S0038-0717(00)00084-5

LAL, R. Digging deeper: A holistic perspective of factors affecting soil organic carbon sequestration in agroecosystems. Global Change Biology, v. 24, p. 3285-3301, 2018. https://doi.org/10.1111/gcb.14054

LAURANCE, W. F.; FERREIRA, L. V.; RANKIN-DE-MERONA, J. M.; LAURANCE, S. G. Rain forest fragmentation and the dynamics of Amazonian tree communities. Ecology, v. 79 , n. 6, p. 2032-2040, 1998. https://doi.org/10.1890/00129658(1998)079[2032:RFFATD]2.0.CO;2 0

LAURANCE, W. F.; VASCONCELOS, H. L. Consequências ecológicas da fragmentação florestal na Amazônia. Oecologia Brasiliensis, v. 13, n. 3, p. 434-451, 2009. https://doi.org/10.4257/oeco.2009.1303.03

LOSS, A.; PEREIRA, M. G.; BEUTLER, S. J.; PERIN, A.; ANJOS, L. H. C. Carbono mineralizável, carbono orgânico e nitrogênio em macroagregados de Latossolo sob diferentes sistemas de uso do solo no Cerrado Goiano. Semina: Ciências Agrárias, v. 34, n. 5, p. 2153-2168, 2013. https://doi.org/10.5433/1679-0359

MAGALHÃES, S. S. A.; RAMOS, F. T.; WEBER, O. L. S. Carbon stocks of an Oxisol after thirty-eight years under different tillage systems. Revista Brasileira de Engenharia Agrícola e Ambiental, v. 20, n. 1, p. 85-91, 2016. https://doi.org/10.1590/18071929/agriambi.v20n1p85-91

MALCHOW, E.; KOEHLER, A. B.; NETTO, S. P. Efeito de borda em um trecho da floresta ombrófila mista, em fazenda Rio Grande, PR. Revista Acadêmica: Ciência Animal, v. 4, n. 2, p. 85-94, 2017. https://doi.org/10.7213/cienciaanimal.v4i2.9357 
MATOS, N. M.; RIBEIRO, F. P.; GATTO, A.; BUSSINGUER, A. P. Estoque de Serapilheira em Três Fisionomias no Cerrado do Distrito Federal. Floresta e Ambiente, v. 24, p. 1-9, 2017. http://dx.doi.org/10.1590/2179-8087.126215

MELO, G. B.; PEREIRA, M. G.; PERIN, A.; GUARESCHI, R. F.; SOARES, P. F. C. Estoques e frações da matéria orgânica do solo sob os sistemas plantio direto e convencional de repolho. Pesquisa Agropecuária Brasileira, v. 51, n. 9, p. 1511-1519, 2016. https://doi.org/10.1590/s0100-204x2016000900050

MENDONÇA, E. S.; MATOS, E. S. Matéria orgânica do solo: métodos de análises. Ponte Nova: D\&M, 2005. 107 p.

NASCIMENTO, H. E. M.; LAURANCE, W. F. Efeitos de área e de borda sobre a estrutura florestal em fragmentos de floresta de terra-firme após 13-17 anos de isolamento. Acta Amazonica, v. 36, n. 2, p. 183-192, 2006. https://doi.org/10.1590/S004459672006000200008

NOGUEIRA, L. R.; SILVA, C. F. D.; PEREIRA, M. G.; GOMES, J. H. G.; SILVA, E. M. R. D. Biological properties and organic matter dynamics of soil in pasture and natural regeneration areas in the Atlantic forest biome. Revista Brasileira de Ciência do Solo, v. 40, p. 1-9, 2016. https://doi.org/10.1590/18069657rbcs20150366

OBOUR, P. B.; JENSEN, J. L.; LAMANDÉ, M.; WATTS, C. W.; MUNKHOLM, L. J. Soil organic matter widens the range of water contents for tillage. Soil \& Tillage Research, v. 182, p. 57-65, 2018. https://doi.org/10.1016/j.still.2018.05.001

OZÓRIO, J. M. B.; ROSSET, J. S.; SCHIAVO, J.; PANACHUKI, E.; SOUZA, C. B. S.; MENEZES, R. S.; XIMENES, T. S.; CASTILHO, S. C. P.; MARRA, L. M. Estoque de carbono e agregação do solo sob fragmentos florestais nos biomas Mata Atlântica e Cerrado. Revista Brasileira de Ciências Ambientais, v. 3, n. 53, p. 97-116, 2019. https://doi.org/10.5327/Z2176-947820190518

PEREIRA, M. A. S.; NEVES, N. A. G. S. Considerações sobre a fragmentação territorial e as redes de corredores ecológicos. Geografia, v. 16, n. 2, p. 5-24, 2007. http://dx.doi.org/10.5433/2447-1747.2007v16n2p5

PRIMACK; R. B.; RODRIGUES, E. Biologia da Conservação. Londrina: Biblioteca Nacional, 2001. 328p.

R CORE TEAM. R: A language and environment for statistical computing. Vienna, 2019.

RANGEL, O. J. P.; SILVA, C. A. Estoques de carbono e nitrogênio e frações orgânicas de Latossolo submetido a diferentes sistemas de uso e manejo. Revista Brasileira de Ciência do Solo, v. 31, p. 1609-1623, 2007. https://doi.org/10.1590/S010006832007000600037

REINSCH, T.; LOGES, R.; KLUB, C.; TAUBE, F. Effect of grassland ploughing and reseeding on $\mathrm{CO} 2$ emissions and soil carbon stocks. Agriculture, Ecosystems \& Environment, v. 265, p. 374-383, 2018. https://doi.org/10.1016/j.agee.2018.06.020

REIS, D. A.; LIMA, C. L. R.; BAMBERG, A. L. Qualidade física e frações da matéria orgânica de um Planossolo sob sistema plantio direto. Pesquisa Agropecuária Brasileira, v. 51, n. 9, p. 1623-1632, 2016. https://doi.org/10.1590/s0100-204x2016000900062 
REIS, V. R. R.; DEON, D. S.; MUNIZ, L. C.; SILVA, M. B.; REGO, C. A. R. M.; GARCIA, U. C.; CANTANHÊDE, I. S. L.; COSTA, J. B. Carbon stocks and soil organic matter quality under different land uses in the maranhense amazon. Journal of Agricultural Science, v. 10, n. 5, p. 329-337, 2018. https://doi.org/10.5539/jas.v10n5p329

ROSSET, J. S.; LANA, M. C.; PEREIRA, M. G.; SCHIAVO, J. A.; RAMPIM, L.; SARTO, M. V. M.; SEIDEL, E. P. Estoque de carbono, propriedades químicas e físicas do solo em sistemas de manejo com diferentes tempos de implantação na Região Oeste do Paraná, Brasil. Semina: Ciências Agrárias, v. 35, n. 6, p. 3053-3072, 2014. http://dx.doi.org/10.5433/1679-0359.2014v35n6p3053

ROSSET, J. S.; ALBERTO, J. S.; MARRA, L. M.; CASTILHO, S. C. P.; OZÓRIO, J. M. B.; LIMA, P. R.; BORSOI, A. SOUZA, L. C. Carbono total e mineralizável do solo adubado com diferentes fontes de fertilizantes e resíduos orgânicos. Global Science and Technology, v. 12, n. 2, 2019a.

ROSSET, J. S.; LANA, M. C.; PEREIRA, M. G.; SCHIAVO, J. A.; RAMPIM, L.; SARTO, M. V. M. Organic matter and soil aggregation in agricultural systems with different adoption times. Semina: Ciências Agrárias, v. 40, n. 6, suplemento 3, p. 3443-3460, 2019b. http://dx.doi.org/10.5433/1679-0359.2019v40n6Supl3p3443

ROSSET, J. S.; LANA, M. C; PEREIRA, M. G.; SCHIAVO, J. A.; RAMPIM, L.; SARTO, M. V. M. Frações químicas e oxidáveis da matéria orgânica do solo sob diferentes sistemas de manejo, em Latossolo Vermelho. Pesquisa Agropecuária Brasileira, v. 51, n. 9, p. 1529-1538, 2016. https://doi.org/10.1590/s0100-204x2016000900052

SAlES, A.; SIlVA, A. R.; VElOSO, C. A. C.; CARVAlHO, E. J. M.; MIRANDA, B. M. Carbono orgânico e atributos físicos do solo sob manejo agropecuário sustentável na Amazônia Legal. Colloquium Agrariae, v. 14, n. 1, p. 1-15, 2018.

SANTOS, H. G.; JACOMINE, P. K. T.; ANJOS, L. H. C.; OLIVEIRA, V. A.; LUMBRERAS, J. F.; COELHO, M. R.; ALMEIDA, J. A.; ARAÚJO FILHO, J. C.; OLIVEIRA, J. B.; CUNHA, T. J. F. Sistema Brasileiro de Classificação de Solos. 5.ed. Brasília: Embrapa, 2018. 356p.

SIGNOR, D.; ZANI, C. F.; PALADINI, A. A.; DEON, M. D.; CERRI, C. E. P. Estoques de carbono e qualidade da matéria orgânica do solo em áreas cultivadas com cana-de-açúcar. Revista Brasileira de Ciência do Solo, v. 38, n. 5, p. 1402-1410, 2014. https://doi.org/10.1590/S0100-06832014000500005

SMITH, P. Soils and climate change. Current Opinion in Environmental Sustainability, v. 4, n. 5, p. 539-544, 2012. https://doi.org/10.1016/j.cosust.2012.06.005

SOUZA, A. C. O. D.; TORRES, R. B.; BERNACCI, L. C.; JUNG-MENDAÇOLLI, S. L. Species of native flora of the remnants from experimental stations of agência paulista de tecnologia dos agronegócios, Instituto Agronômico de Campinas, São Paulo State, Brazil. Hoehnea, v. 42, n. 1, p. 59-92, 2015. https://doi.org/10.1590/2236-8906-29/2014

SOUZA, F. G. D.; MELO, V. F.; ARAÚJO, W. F.; ARAÚJO, T. H. D. C. Losses of soil, water, organic carbon and nutrients caused by water erosion in different crops and natural savannah in the northern Amazon. Revista Ambiente \& Água, v. 14, n. 1, p. 1-16, 2019. https://dx.doi.org/10.4136/ambi-agua.2126 
SOUZA, L. C.; FERNANDES, C.; MOITINHO, M. R.; BICALHO, E. S.; SCALA, N. L. J. R. Soil carbon dioxide emission associated with soil porosity after sugarcane field reform. Mitigation and Adaptation Strategies for Global Change, v. 24, n. 1, p. 1-15, 2018. https://doi.org/10.1007/s11027-018-9800-5

SOUZA, R. P. B.; FREITAS, M. A. M.; COSTA, M. P.; PEREIRA, L. F.; GOMES, J. V. A. Impact of anthropic action on physical attributes of the soil in different physiology of $\begin{array}{lllllllll}\text { Cerrado. Multi-Science Journal, v. } 1, & \text { n. } & \text { 9, p. 28-32, } 2017 .\end{array}$ https://dx.doi.org/10.33837/msj.v1i9.380

SPEROW, M. Marginal cost to increase soil organic carbon using no-till on US cropland. Mitigation and Adaptation Strategies for Global Change, v. 23, p. 1-20, 2018. https://doi.org/10+1007/s11027-018-9799-7

VIANA, V. M.; PINHEIRO, L. A. F. V. Conservação da biodiversidade em fragmentos florestais. Série Técnica IPEF, v. 12, n. 32, p. 25-42, 1998.

VIANA, V. M.; TABANEZ, A. A. J.; BATISTA, J. L. F. Dynamics and restoration of forest fragments in the Brazilian Atlantic moist Forest. In: LAURANCE, W. F.; BIERREGARD, R. O. (ed.). Tropical forest remnants: ecology management and conservation of fragmented communities. Chicago: University of Chicago Press, 1997. p. 351-365.

WADE, J.; CULMAN, S. W.; HURISSO, T. T.; MILLER, R. O.; BAKER, L.; HORWATH, W. R. Sources of variability that compromise mineralizable carbon as a soil health indicator. Soil Science Society of America Journal, v. 82, p. 243-252, 2018. https://dx.doi.or/10.2136/sssaj2017.03.0105

WARBURTON, N. H. Structure and conservation of forest avifauna in isolated rainforest remnants in tropical Australia. In: LAURANCE W. F.; BIERREGAARD R. O. (eds). Tropical Forest Remnants. Chicago: University of Chicago Press, 1997. p. 190-206.

YEOMANS, J. C.; BREMNER, J. M. A rapid and precise method for routine determination of organic carbon in soil. Communications in Soil Science and Plant Analysis, v. 19, n. 13, p. 1467-1476, 2008. https://doi.org/10.1080/00103628809368027 